\title{
Elephant grass ensiled with wheat bran compared with corn silage in diets for lactating goats
}

\author{
Jacianelly Karla da Silva ${ }^{1}$, Juliana Silva de Oliveira ${ }^{1}$, Ariosvalo Nunes de Medeiros', \\ Edson Mauro Santos ${ }^{1}$, Tamires da Silva Magalhães ${ }^{1}$, Alenice Ozino Ramos¹, Higor Fábio \\ Carvalho Bezerra ${ }^{1}$
}

${ }^{1}$ Universidade Federal da Paraíba, Areia, PB, Brasil.

\begin{abstract}
The objective of this study was to evaluate the use of wheat bran as an additive in elephant-grass silage on intake and digestibility of the nutrients, ingestive behavior, and yield and chemical composition of milk. Eight goats with 45 days of lactation were distributed in a $(4 \times 4)$ Latin square design. The treatments consisted of corn silage (CS), elephant-grass silage without wheat bran (EGS), elephant-grass silage with $10 \%$ wheat bran (EGS $+10 \% \mathrm{WB})$, and elephant-grass silage with $20 \%$ wheat bran (EGS $+20 \% \mathrm{WB})$. There was no difference in dry matter (DM) intake between diets EGS and CS in $\mathrm{g} \mathrm{d}^{-1}$. However, the animals fed EGS $+10 \%$ WB had lower DM and organic matter (OM) intakes than the animals fed CS in $\mathrm{g} \mathrm{kg}^{-1} \mathrm{~d}^{-1}$ of body weight. There were lower non-fiber carbohydrate and metabolize energy intakes by animals fed diets based on elephantgrass silages than those fed CS. The EGS $+20 \% \mathrm{WB}$ diet provided lower digestibility coefficients of DM, OM, crude protein, ether extract, neutral detergent fiber (NDF) and digestible nutrients of the diet than the diet with CS. The NDF digestibility coefficient with diet EGS was greater than that obtained with diet CS. The diets with corn and elephant-grass silages provided similar milk yield levels. However, the animals fed diets based on EGS $+20 \%$ WB produced less total-solids-corrected milk than the animals fed CS. No difference was found in the milk physicochemical properties and ingestive behavior of goats in this study. Corn silage can be replaced by elephant-grass silage harvested at 50 days of regrowth and elephant-grass silage with $10 \%$ wheat bran without influencing goat performance, behavioral variables, physiological variables, milk yield or the milk physicochemical properties.
\end{abstract}

Key Words: additive, caprine, ethology, milk, milk composition, nutritive value

\section{Introduction}

Elephant grass can be cultivated in most regions of Brazil. However, the traditional method adopted to use this forage, which is harvested when it is provided to animals, in addition to requiring daily man power, results in low nutritive value during the dry season. In this sense, the conservation of elephant grass harvested during the rainy season guarantees forage of a high nutritional value for the dry season.

In spite of its high nutritional value, the use of corn silage also requires labor and financial investments annually for cultivation, cutting and ensilage of this grass, which normally results in more expensive silage than silage made with elephant grass. Therefore, implementing a technology that enables better use of the grasses to

Received March 27, 2014 and accepted August 25, 2014.

Corresponding author: jacianelly@gmail.com

http://dx.doi.org/10.1590/S1516-35982014001100008

Copyright $@ 2014$ Sociedade Brasileira de Zootecnia. This is an Open Access article distributed under the terms of the Creative Commons Attribution Non-Commercial License, which permits unrestricted non-commercial use, distribution, and reproduction in any medium, provided the original work is properly cited. produce silage would allow for a reduction of the milk production costs.

Elephant grass has low levels of soluble carbohydrates and a high moisture level at the time of cutting, and a high buffering capacity, which hampers the fermentation, and this often results in poor-quality silage. However, the simple use of additives, which can increase the levels of silage dry matter, can improve lactic fermentation, and, consequently, reduce the losses during the ensiling of this grass.

Among the concentrate foods, wheat bran possesses highly favorable characteristics to be used as an additive to elephant-grass silage, because of its low cost, high dry matter, and good nutritional value.

Therefore, an alternative in goat nutrition that also reduces production costs, especially during the dry season in several regions of Brazil, has been the use of elephant grass (Pennissetum purpureum) enriched with wheat bran.

Thus, this work aimed to evaluate the use of wheat bran as additive in elephant-grass silage on intake and digestibility of the nutrients, ingestive behavior, production and chemical composition of goat milk. 


\section{Material and Methods}

The experiment was developed at the Unit for SmallRuminant Research at Universidade Federal da Paraiba.

Eight Saanen $\times$ French Alpine crossbred goats with a mean body weight of $43.5 \pm 4.3 \mathrm{~kg}$, at \pm 45 days in milk at the start of the study, were used. Each animal was treated against endo- and ectoparasites, and then housed in individual stalls on a cement floor, provided with feed and water ad libitum.

The experimental design used was a double Latin square $(4 \times 4)$, with four treatments and four periods. The experiment was composed of four 20-day periods. The first 14 days of each period were used as an adaptation period, while data collected during the last six days were used for statistical analysis.

The diets were composed of silage and concentrate, and they were formulated to be isonitrogenous, balanced to meet or exceed the nutrient requirements of lactating goats with an average yield of $2.5 \mathrm{~kg} \mathrm{~d}^{-1}$ and $4 \mathrm{~g} / 100 \mathrm{~g}$ of milk fat, according to recommendations of NRC (2007). The treatments were represented by the diets with different silages: corn silage (CS); elephant-grass silage without wheat bran (EGS); elephant-grass silage with $10 \%$ wheat bran (EGS $+10 \% \mathrm{WB})$, as is; and elephant-grass silage with $20 \%$ wheat bran (EGS $+20 \% \mathrm{WB})$, as is. Elephant grass was ensiled at 50 days of regrowth and corn was added when the grain was in the dough stage. The cut forage was chopped in a stationary machine to a theoretical length of $2 \mathrm{~cm}$. A grain-storage plastic drum with 200 L capacity was used, and compacted by trampling. Wheat bran was mixed with elephant grass before being placed into the silo.

Feed was supplied twice daily, at $07.30 \mathrm{~h}$ and $16.30 \mathrm{~h}$, and approximately $110 \%$ of the intake of the previous day was provided to ensure ad libitum intake. Refusals were measured daily prior to feeding. Cows had access to fresh clean water at all times.

Dietary ingredients and leftovers were analyzed for dry matter $(\mathrm{DM})$, organic matter $(\mathrm{OM})$, crude protein $(\mathrm{CP})$, ether extract (EE) and mineral matter (MM) according to the methodologies described by Silva and Queiroz (2002) (Tables 1 and 2). To determine lignin, the methodology described by Van Soest (1967) was adopted, by using sulfuric acid $\left(\mathrm{H}_{2} \mathrm{SO}_{4}\right)$ at $72 \%$. To determine the neutral (NDF) and acid (ADF) detergent fiber fractions, a methodology recommended by the manufacturer of the ANKON device (Ankon technology Corporation), was used. In all the samples, NDF and ADF were corrected for ash and protein, the digestion residues in neutral and acid detergent were incinerated in muffle furnace at $600{ }^{\circ} \mathrm{C}$ for $2 \mathrm{~h}$, and the correction for protein was carried out using neutral and acid detergent insoluble protein.

To estimate the non-fiber carbohydrates (NFCap) the equations given by Hall et al. (1999) and Hall et al. (2000) were used, and the NDF was corrected for ash (a) and protein (p) (NDFap):

Total carbohydrates $(\mathrm{TC})=100-(\% \mathrm{CP}+\% \mathrm{EE}+\% \mathrm{ash})$;

NFCap $=100-[(\% \mathrm{CP}-\% \mathrm{CP}$ derived from urea $-\%$ urea) $+\%$ NDFap $+\%$ EE $+\% \mathrm{MM}]$ (diets with urea).

The total digestible nutrients of the diet (TDN) were obtained using apparent digestibility data observed in the experiment, calculated according to Sniffen et al. (1992): $\mathrm{ITDN}=(\mathrm{CP}$ intake $-\mathrm{CP}$ feces $)+2.25 \times(\mathrm{EE}$ intake $-\mathrm{EE}$ feces $)$ $+($ NDF intake - NDF feces $)+($ NFC intake - NFC feces);

$$
\% \mathrm{TDN}=(\mathrm{TDN} \text { intake } / \mathrm{DM} \text { intake }) \times 100
$$

The TDN values of the diets were converted to digestible energy (DE) and metabolizable energy (ME) using the equations described by NRC (2001):

Table 1 - Chemical composition $\left(\mathrm{g} \mathrm{kg}^{-1} \mathrm{DM}\right)$ of the ingredients in experimental diets

\begin{tabular}{|c|c|c|c|c|c|c|c|}
\hline \multirow{2}{*}{ Item } & \multicolumn{7}{|c|}{ Ingredients $\left(\mathrm{g} \mathrm{kg}^{-1}\right)$} \\
\hline & $\mathrm{CM}^{1}$ & SM & WB & $\mathrm{CS}$ & EGS & $\mathrm{EGS}+10 \% \mathrm{WB}$ & $\mathrm{EGS}+20 \% \mathrm{WB}$ \\
\hline Dry matter ${ }^{2}$ & 915.9 & 865.0 & 881.7 & 260.1 & 174.8 & 236.3 & 314.6 \\
\hline Organic matter & 961.4 & 943.0 & 935.0 & 939.7 & 902.3 & 908.7 & 924.4 \\
\hline Crude protein & 111.8 & 500.2 & 160.9 & 73.3 & 77.3 & 123.9 & 135.5 \\
\hline Ether extract & 94.0 & 25.3 & 47.1 & 63.5 & 39.6 & 59.1 & 69.4 \\
\hline Neutral detergent fiber ${ }^{3}$ & 231.9 & 148.7 & 423.4 & 557.0 & 708.3 & 585.6 & 501.6 \\
\hline Acid detergent fiber ${ }^{3}$ & 63.3 & 88.7 & 134.2 & 348.4 & 498.1 & 370.4 & 298.7 \\
\hline Lignin & 24.0 & 19.1 & 49.2 & 98.2 & 99.6 & 71.6 & 65.8 \\
\hline Non-fiber carbohydrate & 522.8 & 227.7 & 303.6 & 245.8 & 77.1 & 142.0 & 207.8 \\
\hline Neutral detergent insoluble protein & 14.5 & 46.7 & 32.2 & 23.1 & 14.7 & 16.8 & 18.8 \\
\hline Acid detergent insoluble protein & 02.9 & 21.0 & 03.9 & 06.9 & 07.1 & 07.3 & 06.5 \\
\hline
\end{tabular}

CM - industrialized corn meal; SM - soybean meal; WB - wheat bran; CS - corn silage; EGS - elephant-grass silage; EGS $+10 \% \mathrm{WB}$ - elephant-grass silage $+10 \%$ wheat bran EGS $+20 \%$ WB - elephant-grass silage $+20 \%$ wheat bran

${ }^{1}$ By-product of the corn flake manufacture.

${ }^{2} \mathrm{~g} \mathrm{~kg}^{-1}$ as is.

${ }_{3}^{3}$ Ash- and protein-free. 
$\mathrm{DE}\left(\mathrm{Mcal} \mathrm{kg}^{-1}\right)=0.04409 \times \mathrm{TDN}(\%) ;$

$\operatorname{ME}\left(\right.$ Mcal kg $\left.^{-1}\right)=1.01 \times$ DE $($ Mcal kg-1 $)-0.45$

The samples of silage were analyzed for lactic acid and volatile fatty acids using High Performance Liquid Chromatography (HPLC) (SHIMADZU, model SPD-10A VP coupled to a Ultra-Violet Detector (UV)) using a $210-n m$ wavelength. For these analyses, the methodology recommended by the manufacturer was used.

For the silage samples, $\mathrm{pH}$ and ammonia nitrogen were analyzed at the laboratory. Samples of $25 \mathrm{~g}$ were extracted, to which $100 \mathrm{~mL}$ of water were added and, after resting for $2 \mathrm{~h}$, the $\mathrm{pH}$ was read by using a potentiometer. In other $25 \mathrm{~g}$ samples, $200 \mathrm{~mL}$ of a solution containing $\mathrm{H}_{2} \mathrm{SO}_{4}$ and $0.2 \mathrm{~N}$ and a solution resting for $48 \mathrm{~h}$ were added, and, then, the filtering process was carried out. The filtered part was stored in a refrigerator for a subsequent analysis of ammonia $\mathrm{N}$ of the silages according to Bolsen et al. (1992), adapted by Cândido (2000).

The dry matter intake (DMI) was determined by recording the feed supplied and left over from d 14 to d 20 for each cow during each period. To determine the digestibility coefficients of DM, OM, CP, EE, NDF and NFC, the feces of the animals were collected directly from the final portion of the rectus all at the same time: $06.00 \mathrm{~h}, 09.00 \mathrm{~h}, 12.00 \mathrm{~h}, 15.00 \mathrm{~h}$ and $18.00 \mathrm{~h}$ on the 16th, 17th, 18th, 19th and 20th days, respectively, of the experimental period. The samples of feces were stored at $-15{ }^{\circ} \mathrm{C}$ and subsequently, as performed with feed and leftovers, they were processed when each experimental period was finished.

The fecal excretion was estimated by using the indigestible neutral detergent fiber (iNDF) as an internal marker. The samples of feces, feed and leftovers were incubated for a period of $240 \mathrm{~h}$ (Casali, 2006).

The coefficient of apparent digestibility (CAD) was calculated as described by Silva and Leão (1979), as follows:

$\mathrm{CAD}=\{[$ Nutrient intake $(\mathrm{kg})-$ Nutrient excreted in the feces $(\mathrm{kg})] /$ nutrient intake $(\mathrm{kg})\} \times 100$

The body weight of the animals was evaluated by weighing them at the beginning and at the end of each experimental period. The dairy control was conducted daily by weighing the milk individually, during the five last days of each experimental period. In the 16th, 18th and 20th days of each experimental period, milk was collected for physicochemical analysis.

Table 2 - Chemical composition of the experimental diets

\begin{tabular}{|c|c|c|c|c|}
\hline \multirow{2}{*}{ Item } & \multicolumn{4}{|c|}{ Diets $\left(\mathrm{g} \mathrm{kg}^{-1}\right)$} \\
\hline & $\mathrm{CS}$ & EGS & $\mathrm{EGS}+10 \% \mathrm{WB}$ & $\mathrm{EGS}+20 \% \mathrm{WB}$ \\
\hline \multicolumn{5}{|l|}{ Proportions of ingredients ( $\left.\mathrm{g} \mathrm{kg}^{-1} \mathrm{DM}\right)$} \\
\hline Corn silage & 554.9 & 00.0 & 00.0 & 00.0 \\
\hline Elephant grass silage & 00.0 & 420.4 & 00.0 & 00.0 \\
\hline Elephant grass silage $+10 \%$ wheat bran & 00.0 & 00.0 & 658.3 & 00.0 \\
\hline Elephant grass silage $+20 \%$ wheat bran & 00.0 & 00.0 & 00.0 & 752.7 \\
\hline Soybean meal & 119.0 & 155.5 & 73.0 & 23.4 \\
\hline Corn meal & 296.3 & 391.5 & 239.8 & 198.2 \\
\hline Urea & 06.9 & 07.7 & 06.9 & 07.0 \\
\hline Mineral mix ${ }^{1}$ & 11.5 & 13.7 & 11.7 & 06.1 \\
\hline Limestone & 11.4 & 11.2 & 10.3 & 12.6 \\
\hline \multicolumn{5}{|l|}{ Chemical composition ( $\left.\mathrm{g} \mathrm{kg}^{-1} \mathrm{DM}\right)$} \\
\hline Dry matter ${ }^{2}$ & 381.0 & 328.4 & 316.3 & 375.6 \\
\hline Organic matter & 918.5 & 902.3 & 897.5 & 908.4 \\
\hline Mineral matter & 81.5 & 97.7 & 102.5 & 91.6 \\
\hline Crude protein & 159.8 & 164.8 & 160.8 & 158.4 \\
\hline Ether extract & 66.1 & 57.4 & 63.2 & 79.1 \\
\hline Neutral detergent fiber ${ }^{3}$ & 395.5 & 411.7 & 452.0 & 427.0 \\
\hline Acid detergent fiber ${ }^{3}$ & 222.7 & 298.6 & 265.5 & 239.4 \\
\hline Lignin & 63.9 & 54.3 & 54.3 & 54.8 \\
\hline Non-fiber carbohydrate & 317.0 & 271.0 & 232.6 & 263.6 \\
\hline Neutral detergent insoluble protein & 22.7 & 19.1 & 17.9 & 18.2 \\
\hline Acid detergent insoluble protein & 07.2 & 07.4 & 07.1 & 05.9 \\
\hline
\end{tabular}


After each period of collection, the milk was analyzed in the laboratory. The milking procedures and manipulation of milk were performed according to the recommendations based on the Technical Regulation on Production, Identity and Quality of Goat Milk (Brasil, 2000).

In the milk physicochemical analysis, the levels of total nitrogen $(\mathrm{TN})$ were determined and then the protein content was calculated as follows: $\mathrm{CP}=\mathrm{TN} \times 6.38$, by the microKjedahl method (AOAC methods 991.20 and 991.23) (AOAC, 1998); total dry extract, by drying until obtaining constant weight (AOAC method 925.23) (AOAC, 1998); lipids, by using Gerber's lactobutyrometer (IAL, 2005); and lactose (in g/100 g), by Fehling's test (IAL, 2005). Also, the density index was read on a thermolactodensimeter at $15^{\circ} \mathrm{C}$ (IAL, 2005) and acidity, which was expressed in ${ }^{\circ} \mathrm{D}$ (AOAC method 947.05) (AOAC, 1998).

Results of the analyses of milk fat percentage were utilized to convert milk yield to $4.0 \%$-fat-corrected milk (4\%FCMY), according to NRC (2001), using the following formula:

$4 \%$ FCMY $\left(\mathrm{kg} \mathrm{d}^{-1}\right)=0.4 \times$ milk $\left(\mathrm{kg} \mathrm{d}^{-1}\right)+15 \times$ fat $\left(\mathrm{kg} \mathrm{d}^{-1}\right)$

The correction for the milk total solids was carried out according to Tyrrel and Reid (1965), by using the equation:

TSMY $=(12.3 \times \mathrm{g}$ of fat $)+(6.56 \times \mathrm{g}$ of milk-solids-nonfat $)$

$$
-(0.0752 \times \mathrm{kg} \text { of milk). }
$$

The ingestive behavior of the animals was observed from $06.00 \mathrm{~h}$ of the fifth day of each period to $06.00 \mathrm{~h}$ of the following day (seventh day), and visually, by the method of instant scan, proposed by Martin and Bateson (1986). The animals were analyzed by trained observers, which were strategically positioned so as not to disturb the animals. At every five minutes the times spent feeding, ruminating and idle were determined by using a digital chronometer (Johnson and Combs, 1991). Besides these variables, the number of times that animals sought water, defecated and urinated were also recorded and visually observed. During all the experimental period, the animals were kept under artificial lighting for their adaptation, for the observations performed at night.

The following variables were also calculated:

$\mathrm{FE}_{\mathrm{DM}}=\mathrm{DMI} / \mathrm{FT}\left(\mathrm{kg} \mathrm{DM} \mathrm{h}^{-1}\right) ; \mathrm{FE}_{\mathrm{NDF}}=\mathrm{NDFI} / \mathrm{FT}\left(\mathrm{kg} \mathrm{NDF} \mathrm{h}^{-1}\right)$; $\mathrm{RE}_{\mathrm{DM}}=\mathrm{DMI} / \mathrm{RT}\left(\mathrm{kg} \mathrm{DM} \mathrm{h}^{-1}\right) ; \mathrm{RE}_{\mathrm{NDF}}=\mathrm{NDFI} / \mathrm{RT}\left(\mathrm{kg} \mathrm{NDF} \mathrm{h}^{-1}\right)$; $\mathrm{TCT}=\mathrm{FT}+\mathrm{RT}\left(\mathrm{h} \mathrm{d}^{-1}\right) ; \mathrm{NRB}=\mathrm{RT} / \mathrm{TRCB}\left(\mathrm{nd}^{-1}\right)$; and NRCD $=\mathrm{NRB} \times \mathrm{NRCB}\left(\mathrm{n} \mathrm{d}^{-1}\right)$. Polli et al. (1996) describe these variables as follows: $\mathrm{FE}=$ feeding efficiency $(\mathrm{kg} \mathrm{DM}$ or NDF $\left.\mathrm{h}^{-1}\right)$; DMI $=$ dry matter intake $\left(\mathrm{kg} \mathrm{DM} \mathrm{d}^{-1}\right) ; \mathrm{FT}=$ feeding time $\left(\mathrm{h} \mathrm{d}^{-1}\right) ; \mathrm{RE}=$ rumination efficiency $(\mathrm{kg} \mathrm{DM}$ or $\left.\mathrm{NDF} \mathrm{h}{ }^{-1}\right)$; RT = rumination time $\left(\mathrm{h} \mathrm{d}^{-1}\right)$; TCT = total chewing time $\left(\mathrm{h} \mathrm{d}^{-1}\right)$; NRB $=$ number of ruminal boluses $\left(\mathrm{n} \mathrm{d}^{-1}\right)$; and
$\mathrm{TRCB}=$ time spent on rumination chews per ruminal bolus ( $\mathrm{h}$ bolus ${ }^{-1}$ ). According to Bürger et al. (2000), NRCD = number of rumination chews per day $\left(\mathrm{n} \mathrm{d}^{-1}\right)$; and $\mathrm{NRCB}=$ number of rumination chews per bolus ( $\mathrm{n}$ bolus ${ }^{-1}$ ).

On the same day, the number of rumination chews $\left(\mathrm{n}\right.$ bolus ${ }^{-1}$ ) and the time spent on the rumination of each bolus $\left(\mathrm{s} \mathrm{bolus}^{-1}\right)$ were counted. For this evaluation, three ruminal boluses were observed in three periods of the day (10-12; 14-16; 19-21 h), using a digital chronometer. The average number of rumination chews and the time elapsed were used for these analyses.

The data were analyzed using the MIXED procedure of SAS (Statistical Analysis System, version 9.2). The contrasts were tested by Dunnett's test at the level of significance at 0.05 , comparing the treatment with corn silage (control) with the other treatments.

\section{Results and Discussion}

By analyzing the $\mathrm{pH}$ values of the studied silages (Table 3), it was found that the highest value was that of the silage of elephant grass (4.383) and the lowest was found at EGS $+20 \%$ WB (3.940). Thus, no silages showed $\mathrm{pH}$ values under 3.80 or above 4.50 , which would classify the silages as good quality (Lanes et al., 2006).

Generally, it is considered that silages with less than $10 \%$ of $\mathrm{N}-\mathrm{NH}_{3} \mathrm{TN}^{-1}$ show an efficient fermentation for the conservation of the ensiled material (Ferreira, 2001). Thus, the $\mathrm{N}-\mathrm{NH}_{3} \mathrm{TN}^{-1}$ values obtained in this work are below the $10 \% \mathrm{~N}^{-\mathrm{NH}_{3}} \mathrm{TN}^{-1}$, and this can also be indicative that the silages are well-fermented (Table 3).

The acids commonly used to evaluate the quality of the fermentative process of the silages are lactic, butyric and acetic acids. The lactic acid should appear at a higher percentage than the others, although all the acids formed in fermentation contribute with $\mathrm{pH}$ reduction of the silage. Therefore, the percentages of lactic acid in the analyzed silages were higher than those of the other acids, but within the standards recommended by Lanes et al. (2006), which is from 3 to $8 \%$ in the dry matter, and this allows us to infer that the silages probably did not undergo undesirable fermentations.

As regards butyric acid, it should always appear in small amounts, because its presence reveals intense protein degradation. Hence, as the amount of volatile nitrogen as percentage of the total nitrogen increases, the quality of silages is decreased, indicating degradation of protein compounds. The butyric acid content of DM of diets ranged from $0.40 \mathrm{~g} \mathrm{~kg}^{-1}$ to $0.62 \mathrm{~g} \mathrm{~kg}^{-1}$, and it can be considered that the butyric acid contents of the silages under study did 
not affect the fermentation process, because values lower than $0.1 \%$ of DM were shown, which is in agrement with Lanes et al. (2006).

The corn silage presented the lowest value of acetic acid (7.36 $\mathrm{g} \mathrm{kg}^{-1} \mathrm{DM}$ ), while the elephant-grass silages displayed the highest value (12.89 $\left.\mathrm{g} \mathrm{kg}^{-1} \mathrm{DM}\right)$. These results indicate that all the analyzed silages presented good fermentation, since acetic acid was lower than $2 \%$ in the dry matter.

The elephant-grass silage without additives resulted in $\mathrm{pH}$ value and contents of ammonia nitrogen and organic acids within the recommended standards. This fact can be explained by the high soluble-carbohydrate contents found in grasses cultivated in low-temperature regions, which might have contributed to the good fermentation of these silages (Harris and James, 1969). In this way, it is possible that, despite its low dry matter contents, the high concentrations of soluble carbohydrates in the elephant-grass silage ensured good fermentation of the ensiled mass.

There was no difference in DM intake (DMI) $(\mathrm{P}>0.05)$ between the diets based on elephant grass and corn silage in $\mathrm{g} \mathrm{d}^{-1}$ (Table 4). However, the animals fed diets based on elephant-grass silage with $10 \%$ wheat bran presented lower dry matter intake than the animals fed corn silage $(\mathrm{P}<0.05)$ in $\mathrm{g} \mathrm{kg}^{-1} \mathrm{~d}^{-1}$ of body weight (BW) and $\mathrm{g} \mathrm{kg}^{-1} \mathrm{~d}^{-1} \mathrm{BW}^{0.75}$. The high neutral detergent fiber content (NDF) observed in the elephant-grass silage with $10 \%$ wheat bran could have contributed to this level of DM intake (Table 2).

Several studies have shown a negative correlation between DM intake and the dietary NDF content. Such correlation has been associated with a lower passage rate of NDF regarding the other dietary components, which, in turn, promotes reticulo-rumen fill, increasing the bolus residence time in these compartments (Menezes et al., 2004).

The low DM intake in the animals fed diets with elephant-grass silage with $10 \%$ wheat bran resulted in a low organic matter intake in $\mathrm{g} \mathrm{kg}^{-1} \mathrm{~d}^{-1}$ of $\mathrm{BW}$ when compared with the animals fed corn silage (Table 4). The diet containing elephant-grass silage with $20 \%$ wheat bran also resulted in a low organic matter intake than the diet with corn silage.

The CP intake (CPI) was similar between corn and elephant-grass silages. Only the diets with corn silage (CPI of $310.02 \mathrm{~g} \mathrm{~d}^{-1}$ ) and elephant grass-silage without wheat bran (CPI of $280.04 \mathrm{~g} \mathrm{~d}^{-1}$ ) reached the CPI requirements (278.00 $\left.\mathrm{g} \mathrm{d}^{-1}\right)$ recommended by NRC (2007) for dairy goats under the conditions in this study. The diets with EGS $+10 \%$ $\mathrm{WB}$ and $\mathrm{EGS}+20 \% \mathrm{WB}$ provided the crude protein intakes of $250.06 \mathrm{~g} \mathrm{~d}^{-1}$ and $240.08 \mathrm{~g} \mathrm{~d}^{-1}$, respectively, and they were below the $\mathrm{CP}$ requirements for lactating goats.

Table 3 - pH values, ammonia nitrogen as a percentage of total nitrogen, and organic acids in corn and elephant-grass silages with and without addition of wheat bran

\begin{tabular}{lcccc}
\hline \multirow{2}{*}{ Parameters } & \multicolumn{3}{c}{ Treatments (Diets) } \\
\cline { 2 - 5 } & $\mathrm{CS}$ & EGS & EGS+10\%WB & EGS+20\%WB \\
\hline $\mathrm{pH}$ & 3.728 & 4.383 & 4.090 & 3.940 \\
$\mathrm{~N}-\mathrm{NH}_{3}\left(\mathrm{~g} \mathrm{~kg}^{-1}\right.$ total $\left.\mathrm{N}\right)$ & 38.13 & 86.82 & 46.25 & 35.03 \\
Lactic acid $\left(\mathrm{g} \mathrm{kg}^{-1} \mathrm{DM}\right)$ & 31.56 & 33.58 & 32.17 & 28.64 \\
Acetic acid $\left(\mathrm{g} \mathrm{kg}^{-1} \mathrm{DM}\right)$ & 7.36 & 12.89 & 11.19 & 9.11 \\
Propionic acid $\left(\mathrm{g} \mathrm{kg}^{-1} \mathrm{DM}\right)$ & 3.19 & 3.57 & 2.33 & 0.61 \\
Butyric acid $\left(\mathrm{g} \mathrm{kg}^{-1} \mathrm{DM}\right)$ & 0.40 & 0.62 & 0.32 & 0.52 \\
\hline
\end{tabular}

CS - corn silage; EGS - elephant-grass silage; EGS $+10 \% \mathrm{WB}$ - elephant-grass silage $+10 \%$ wheat bran; EGS $+20 \% \mathrm{WB}-$ elephant-grass silage $+20 \%$ wheat bran.

Table 4 - Intakes of chemical components by goats fed corn or elephant-grass silages with and without addition of wheat bran

\begin{tabular}{|c|c|c|c|c|c|c|c|c|}
\hline \multirow{2}{*}{ Parameters } & \multicolumn{4}{|c|}{ Treatments (Diets ) } & \multirow{2}{*}{ CV $(\%)$} & \multicolumn{3}{|c|}{ Contrast } \\
\hline & $\mathrm{CS}$ & EGS & $\mathrm{EGS}+10 \% \mathrm{WB}$ & $\mathrm{EGS}+20 \% \mathrm{WB}$ & & $\mathrm{EGS} \times \mathrm{CS}$ & $\mathrm{EGS}+10 \% \mathrm{WB} \times \mathrm{CS}$ & $\mathrm{EGS}+20 \% \mathrm{WB} \times \mathrm{CS}$ \\
\hline $\mathrm{DMI}\left(\mathrm{g} \mathrm{d}^{-1}\right)$ & $1,900.05$ & $1,600.03$ & $1,490.02$ & $1,520.08$ & 13.485 & ns & ns & ns \\
\hline DMI $\left(\mathrm{g} \mathrm{kg}^{-1} \mathrm{~d}^{-1} \mathrm{BW}\right)$ & 42.11 & 35.34 & 33.25 & 33.87 & 14.465 & ns & $*$ & $\mathrm{~ns}$ \\
\hline DMI $\left(\mathrm{g} \mathrm{kg}^{-1} \mathrm{~d}^{-1} \mathrm{BW}^{0.75}\right)$ & $11,290.02$ & $9,440.09$ & $8,920.01$ & $9,020.04$ & 15.886 & ns & $*$ & ns \\
\hline OMI $\left(\mathrm{g} \mathrm{kg}^{-1} \mathrm{~d}^{-1} \mathrm{BW}\right)$ & 38.78 & 31.86 & 29.73 & 30.62 & 14.443 & ns & $*$ & $*$ \\
\hline $\mathrm{CPI}\left(\mathrm{g} \mathrm{d}^{-1}\right)$ & 310.02 & 280.04 & 250.06 & 240.08 & 13.491 & ns & ns & ns \\
\hline EEI $\left(\mathrm{g} \mathrm{kg}^{-1} \mathrm{~d}^{-1} \mathrm{BW}\right)$ & 2.91 & 2.13 & 2.27 & 2.99 & 15.161 & $*$ & $*$ & ns \\
\hline NDFI $\left(\mathrm{g} \mathrm{kg}^{-1} \mathrm{~d}^{-1} \mathrm{BW}\right)$ & 17.15 & 14.84 & 15.71 & 15.29 & 14.623 & ns & ns & ns \\
\hline NFCI $\left(\mathrm{g} \mathrm{kg}^{-1} \mathrm{~d}^{-1} \mathrm{BW}\right)$ & 13.87 & 9.54 & 7.88 & 9.22 & 18.716 & $*$ & $*$ & $*$ \\
\hline MEI (Mcal d $\left.{ }^{-1}\right)$ & 4.966 & 3.979 & 3.310 & 3.060 & 15.365 & $*$ & $*$ & * \\
\hline
\end{tabular}

$\mathrm{CV}$ - coefficient of variation; BW - body weight; ns - not significant; * Significant comparisons $(\mathrm{P}<0.05)$ by Dunnett's test.

CS - corn silage; EGS - elephant-grass silage without wheat bran; EGS $+10 \% \mathrm{WB}$ - elephant-grass silage $+10 \%$ wheat bran (as is); EGS $+20 \% \mathrm{WB}-$ elephant-grass silage $+20 \%$ wheat bran (as is).

DMI - dry matter intake; OMI - organic matter intake; CPI - crude protein intake; EEI - ether extract intake; NDFI - neutral detergent fiber intake; NFCI - non-fiber carbohydrate intake; MEI - metabolizable energy intake. 
The intake of EE was similar among animals fed diets with corn silage and elephant-grass silage with $20 \%$ wheat bran (Table 4). The ingestion of lipids by animals fed corn silage were higher $(\mathrm{P}<0.05)$ than that of groups fed elephant grass-silage without wheat bran and elephant-grass silage with $10 \%$ wheat bran. The higher percentage of EE was observed in the diets with corn silage and elephant-grass silage with $20 \%$ wheat bran (Table 2). This allowed the lipid intake by animals fed those silages to be higher than other groups.

The intake of neutral detergent fiber did not vary among the diets $(\mathrm{P}>0.05)$ when it was expressed in $\mathrm{g} \mathrm{kg}^{-1} \mathrm{~d}^{-1} \mathrm{BW}$. The diets with corn silage provided higher average NFC intake values than the diets with elephant-grass silages. This fact can be related to the higher NFC contents present in corn silage (Table 1).

The diet with corn silage provided higher values of metabolizable energy intake (MEI) as compared with the animals that consumed the diets with elephant-grass silages $(\mathrm{P}<0.05)$ (Table 4). The animals fed corn silage had the highest intakes of NFC. The NFC is a nutrient of high digestibility and high energy value; hence, this fraction provides higher energy content than NDF to the animals.

The diets with EGS+10\% WB and EGS+20\% WB had lower digestibility coefficients of dry matter $\left(439.87 \mathrm{~g} \mathrm{~kg}^{-1}\right.$ and $519.98 \mathrm{~g} \mathrm{~kg}^{-1}$, respectively) and organic matter (487.88 $\mathrm{g} \mathrm{kg}^{-1}$ and $552.93 \mathrm{~g} \mathrm{~kg}^{-1}$, respectively) than the diet with corn silage. This result can be attributed to the higher amount of fiber fraction in the diets containing elephant-grass silages with $10 \%$ and $20 \%$ wheat bran (Table 2). Furthermore, these diets had the lowest inclusion of soybean meal (source of true protein) and the highest inclusion of urea (source of non-true protein). This could modify the digestibility of the other nutrients of diets, which influenced directly the DM and OM digestibility coefficients.
It was observed that the diet with elephant grass-silage without wheat bran presented similar crude protein digestibility coefficients than corn silage. The EGS $+10 \% \mathrm{WB}$ and EGS $+20 \%$ WB diets had lower digestibility coefficients than corn silage, with $697.14 \mathrm{~g} \mathrm{~kg}^{-1}$ and $612.22 \mathrm{~g} \mathrm{~kg}^{-1}$, respectively. The low crude protein digestibility observed in this diet can be associated with the high fiber contents recorded in silage, regarding the activity of the ruminal microorganisms on the cell content, which resulted in reduced digestibility of nitrogen compounds together with the low true protein content of the diet (Table 2).

In this study there was influence $(\mathrm{P}<0.05)$ of the diets on EE digestibility. The EGS $+20 \% \mathrm{WB}$ diet had lower EE digestibility compared with diet with corn silage. There was no difference in EE digestibility coefficient among the other diets.

The NDF digestibility coefficient in the diet with elephant-grass silage without wheat bran was greater than corn silage. However, the NDF digestibility contained in the corn-silage diet was greater than the diet with elephantgrass silages with $10 \%$ and $20 \%$ wheat bran. The diets did not affect the digestibility of non-fiber carbohydrates (Table 5). The lowest TDN digestibility rates were observed in diets with EGS $+0 \% \mathrm{WB}\left(679.73 \mathrm{~g} \mathrm{~kg}^{-1}\right), \mathrm{EGS}+10 \% \mathrm{WB}$ (608.90 $\mathrm{g} \mathrm{kg}^{-1}$ ), and EGS+20\%WB (553.89 $\mathrm{g} \mathrm{kg}^{-1}$ ) as compared with the corn silage. The highest digestibility coefficient was found with the corn silage ( $715.33 \mathrm{~g} \mathrm{~kg}^{-1}$ ), attributed to the high NFC content of that silage (Table 2).

Regardless of whether milk yield was $4 \%$-fat-corrected or not, the diets with corn and elephant-grass silages yielded similar amount of milk (Table 6). However, the animals fed diets based on elephant-grass silage with $20 \%$ wheat bran showed lower milk yield corrected for total solids than the animals fed corn silage $(\mathrm{P}<0.05)$.

The high milk yield can be related to the high dry matter and crude protein intakes by the animals that received corn silage, elephant-grass silage and elephant-

Table 5 - Apparent digestibility coefficients of the nutrients in dairy goats fed corn or elephant-grass silages with and without addition of wheat bran

\begin{tabular}{|c|c|c|c|c|c|c|c|c|}
\hline \multirow{2}{*}{ Parameters } & \multicolumn{4}{|c|}{ Treatments - diets $\left(\mathrm{g} \mathrm{kg}^{-1}\right)$} & \multirow{2}{*}{$\mathrm{CV}(\%)$} & \multicolumn{3}{|c|}{ Contrast } \\
\hline & $\mathrm{CS}$ & EGS & $\mathrm{EGS}+10 \% \mathrm{WB}$ & $\mathrm{EGS}+20 \% \mathrm{WB}$ & & $\mathrm{EGS} \times \mathrm{CS}$ & $\mathrm{EGS}+10 \% \mathrm{WB} \times \mathrm{CS}$ & $\mathrm{EGS}+20 \% \mathrm{WB} \times \mathrm{CS}$ \\
\hline Dry matter & 615.33 & 640.90 & 519.98 & 439.77 & 6.755 & ns & $*$ & $*$ \\
\hline Organic matter & 645.39 & 668.79 & 552.93 & 487.88 & 5.663 & ns & $*$ & $*$ \\
\hline Crude protein & 701.57 & 767.17 & 697.14 & 612.22 & 6.063 & $*$ & ns & $*$ \\
\hline Ether extract & 787.09 & 766.99 & 758.39 & 679.54 & 8.235 & ns & ns & $*$ \\
\hline Neutral detergent fiber & 366.48 & 428.30 & 314.72 & 218.68 & 10.756 & $*$ & $*$ & $*$ \\
\hline Non-fiber carbohydrates & 926.95 & 932.08 & 927.91 & 900.84 & 4.369 & $\mathrm{~ns}$ & ns & ns \\
\hline Total digestible nutrients & 715.33 & 679.73 & 608.90 & 553.89 & 4.799 & $*$ & $*$ & $*$ \\
\hline
\end{tabular}

CV - coefficient of variation; ns - not significant; * Significant comparisons $(\mathrm{P}<0.05)$ by Dunnett's test.

CS - corn silage; EGS - elephant-grass silage without wheat bran; EGS $+10 \%$ WB - elephant-grass silage $+10 \%$ wheat bran (as is); EGS $+20 \%$ WB - elephant-grass silage $+20 \%$ wheat bran (as is) 
grass silage with $10 \%$ wheat bran. A high feed intake results in more supply of nutrients to the animal, and consequently higher milk production. In addition, the dietary protein is degraded and made available in the bloodstream in the form of amino acids and peptides, and it can be used in the synthesis of milk protein or even in the synthesis of glucose (neoglucogenesis), increasing the production (Alves et al., 2010).

Furthermore, the low milk yield corrected for total solids of the goats fed diets with elephant-grass silage with $20 \%$ wheat bran $\left(1.197 \mathrm{~kg} \mathrm{~d}^{-1}\right)$ can be directly related to DM intake and mainly to the low CP intake remaining below $278 \mathrm{~g} \mathrm{~d}^{-1}$ as stated by NRC (2007), and this may have influenced the production negatively.

No difference was found in the physicochemical composition of the milk from goats in this study (Table 6).

The lactose values obtained in this experiment are close to the $4.30 \mathrm{~g} / 100 \mathrm{~g}$ of milk recommended by the legislation in Brazil for goat milk (Brasil, 2000). However, the lactose content of milk provided by the diets with EGS $+10 \% \mathrm{WB}$ (4.153 g/100 g of milk) and EGS $+20 \%$ WB ( $4.107 \mathrm{~g} / 100 \mathrm{~g}$ of milk) showed values below the minimum limit determined by legislation (Brasil, 2000). Probably, these diets provided lower production of propionate, which is an important precursor of glucose, by reducing the lactose synthesis in the mammary gland.

The corn and soybean meal showed higher nonfiber carbohydrate contents than wheat bran (Table 2). Thus, when the wheat bran was added to the elephantgrass silages, the concentration of corn and soybean meal decreased, resulting in a decrease in NFC intake by animals (Table 4) and probably reduced the production of propionate in rumen and, consequently, the lactose content of milk.

Lactose is one of the most stable nutrients in the milk chemical composition, and it is directly related to the regulation of the osmotic pressure, such that a higher production of lactose determines higher milk production. The highest lactose contents associated with higher milk production were found in the diets with corn silage $(4.536 \mathrm{~g} / 100 \mathrm{~g}$ of milk) and EGS (4.341 g/100 g of milk), which were probably influenced by the higher levels of corn and soybean meal in the diets.

The milk production and its quality depend mainly on the appropriate supply of protein and energy in the diet. The energy necessary for the metabolism of ruminant animals depends on volatile fatty acids (acetic, propionic and butyric) produced in the rumen through the fermentation of different feeds and, depending on the diet composition, a variation between the proportion of the acetic and butyric fatty acids, which are precursor metabolites of part of milk fat, and propionic acid, which is a precursor of milk lactose and responsible for the milk volume.

There was no significant difference with the addition of wheat to elephant-grass silages $(\mathrm{P}>0.05)$ (Table 7) regarding behavioral variables such as time spent on feeding, rumination, total chewing and idle, and feeding and rumination efficiencies according to the intakes of DM and NDF. The FE of animals fed elephant-grass silage with $20 \%$ wheat bran was lower than that of the animals fed corn silage (Table 4).

Table 6 - Milk yield and physicochemical composition of milk from goats fed corn or elephant-grass silages with and without addition of wheat bran

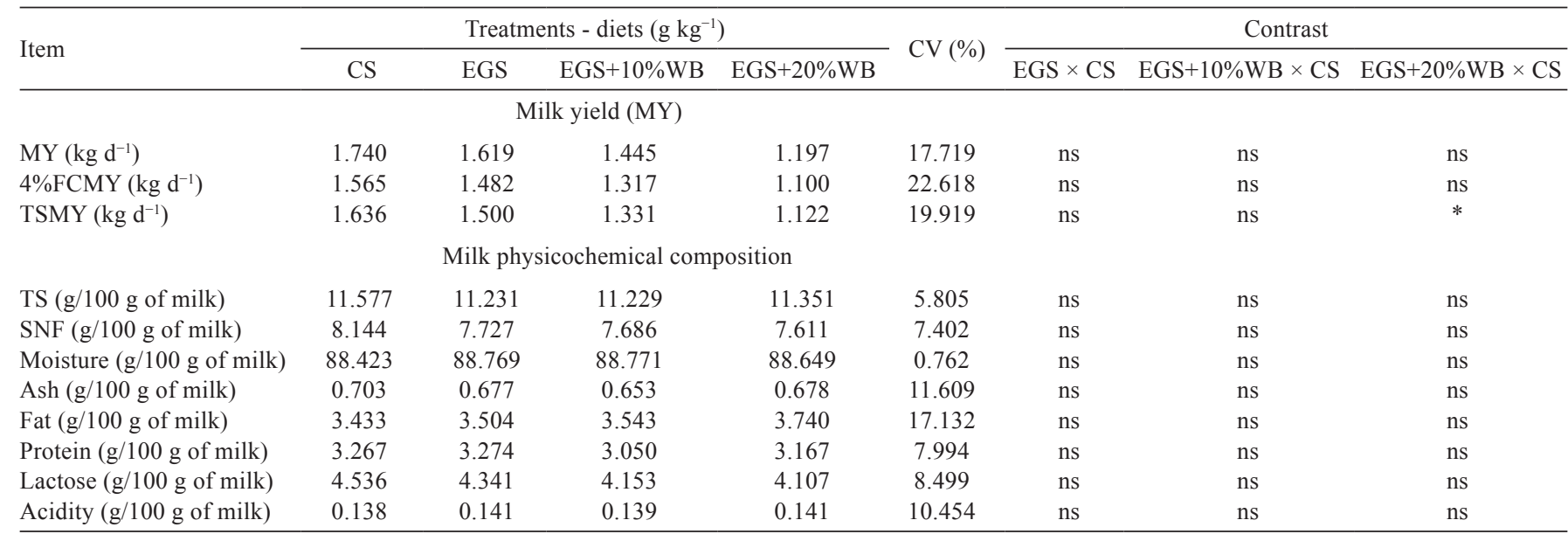

CV - coefficient of variation; - not significant.

CS - corn silage; EGS - elephant-grass silage without wheat bran; EGS $+10 \% \mathrm{WB}$ - elephant-grass silage $+10 \%$ wheat bran (as is); EGS $+20 \% \mathrm{WB}-$ elephant-grass silage $+20 \%$ wheat bran (as is).

4\%FCMY - 4\%-fat-corrected milk yield; TSMY - total-solids-corrected milk yield; TS - total solids; SNF - solids nonfat. 
According to Van Soest (1994), the content and form of fiber from the diet are the main factors affecting the rumination time. Diets composed of sources of fiber from roughages provide a favorable environment for a good functioning of rumen; additionally, the particle size determines the time of residence in rumen, maintaining the chewing activity.

Dulphy et al. (1980) reported that the increase in cell wall components promotes a longer total chewing time. Because in the present work the cell wall components were similar among the diets (Table 7), there were no differences in chewing time. The total chewing time is also related to dry matter intake. However, there was a difference in the dry matter intake, but it was not sufficient to express differences among the diets, which explains the similarity in total chewing time among the evaluated diets.

The variables $(\mathrm{P}>0.05)$ number of ruminal boluses per day (NRB), number of rumination chews per day (NRCD), number of rumination chews per bolus (NRCB), and time on rumination chews per bolus (TRCB, $\mathrm{s}^{-1}$ ) of lactating goats subjected to elephant-grass silages with addition of wheat bran were not affected (Table 7).
Regarding the variables NRCD and NRB, there were no significant effects of diet. This result suggests that the number of rumination chews is directly proportional to the number of ruminal boluses, since the number of daily chews increases with the number of ruminal boluses per day.

With regard to the frequency of defecation, urination and the activity of seeking water, no differences were found $(\mathrm{P}<0.05)$ (Table 8).

Elephant-grass silage without additives and with $10 \%$ wheat bran in the diet of lactating goats provided similar performance, milk physicochemical composition and ingestive behavior as compared with the corn silage. Therefore, elephant-grass silage can replace the corn silage in the diet for lactating goats.

The ground-corn and soybean-meal concentrates are the ingredients that elevate the costs with feeding, since the diet with elephant grass with $10 \%$ wheat bran has a lower amount of those concentrates, but provides equal milk yield to corn- and elephant-grass silages. This means that a diet containing elephant-grass silage with $10 \%$ wheat bran can be economically feasible for the producer.

Table 7 - Behavioral variables of dairy goats fed corn or elephant-grass silages with and without addition of wheat bran

\begin{tabular}{|c|c|c|c|c|c|c|c|c|}
\hline \multirow{2}{*}{ Activities } & \multicolumn{4}{|c|}{ Treatments (Diets) } & \multirow{2}{*}{$\mathrm{CV}(\%)$} & \multicolumn{3}{|c|}{ Contrast } \\
\hline & $\mathrm{CS}$ & EGS & $\mathrm{EGS}+10 \% \mathrm{WB}$ & $\mathrm{EGS}+20 \% \mathrm{WB}$ & & $\mathrm{EGS} \times \mathrm{CS}$ & $\mathrm{EGS}+10 \% \mathrm{WB} \times \mathrm{CS}$ & $\mathrm{EGS}+20 \% \mathrm{WB} \times \mathrm{CS}$ \\
\hline TFT $\left(\mathrm{h} \mathrm{d}^{-1}\right)$ & 4.935 & 4.602 & 4.583 & 4.737 & 26.329 & ns & ns & $\mathrm{ns}$ \\
\hline TRT $\left(\mathrm{h} \mathrm{d}^{-1}\right)$ & 7.561 & 8.138 & 7.759 & 7.371 & 17.853 & ns & ns & ns \\
\hline $\operatorname{TCT}\left(\mathrm{h} \mathrm{d}^{-1}\right)$ & 12.496 & 12.740 & 12.343 & 12.108 & 19.613 & ns & ns & $\mathrm{ns}$ \\
\hline IT $\left(\mathrm{h} \mathrm{d}^{-1}\right)$ & 11.504 & 11.260 & 11.657 & 11.892 & 12.600 & ns & ns & ns \\
\hline NRB & 173.105 & 177.543 & 172.955 & 164.306 & 19.422 & $\mathrm{~ns}$ & ns & $\mathrm{ns}$ \\
\hline NRCD & $32,801.372$ & $34,175.338$ & $33,813.511$ & $30,425.916$ & 21.829 & ns & ns & ns \\
\hline NRCB & 189.800 & 195.633 & 183.100 & 182.400 & 12.878 & ns & ns & ns \\
\hline TRCB & 147.000 & 156.000 & 144.733 & 138.333 & 11.100 & ns & ns & ns \\
\hline \multicolumn{9}{|l|}{ Efficiency } \\
\hline $\mathrm{FE}\left(\mathrm{kg} \mathrm{DM} \mathrm{h}^{-1}\right)$ & 0.490 & 0.377 & 0.350 & 0.400 & 30.919 & ns & ns & ns \\
\hline $\mathrm{FE}\left(\mathrm{kg} \mathrm{NDF}^{-1}\right)$ & 0.200 & 0.157 & 0.165 & 0.179 & 29.933 & ns & ns & ns \\
\hline $\operatorname{RE}\left(\mathrm{kg} \mathrm{DM} \mathrm{h}^{-1}\right)$ & 0.257 & 0.199 & 0.197 & 0.217 & 19.286 & ns & $*$ & $\mathrm{~ns}$ \\
\hline $\operatorname{RE}\left(\operatorname{kg~NDF~}^{-1}\right)$ & 0.104 & 0.083 & 0.093 & 0.098 & 19.517 & ns & ns & $\mathrm{ns}$ \\
\hline
\end{tabular}

$\mathrm{CV}$ - coefficient of variation; ns - not significant; * Significant comparisons $(\mathrm{P}<0.05)$ by Dunnett's test.

CS - corn silage; EGS - elephant-grass silage without wheat bran; EGS $+10 \% \mathrm{WB}$ - elephant-grass silage $+10 \%$ wheat bran (as is); EGS $+20 \% \mathrm{WB}-$ elephant-grass silage $+20 \%$ wheat bran (as is).

TFT - total feeding time; TRT - total rumination time; TCT - total chewing time; IT - idle time; NRB - number of ruminal boli; NRCD - number of rumination chews per day; $\mathrm{NRCB}$ - number of rumination chews per bolus; TRCB - time of rumination chews per bolus $\left(\mathrm{s}^{-1}\right)$; FE - feeding efficiency; RE - rumination efficiency.

Table 8 - Urination, defecation and water-ingestion frequencies by dairy goats fed corn or elephant-grass silages with and without addition of wheat bran

\begin{tabular}{|c|c|c|c|c|c|c|c|c|}
\hline \multirow{2}{*}{ Activities } & \multicolumn{4}{|c|}{ Treatments (Diets) } & \multirow{2}{*}{$\mathrm{CV}(\%)$} & \multicolumn{3}{|c|}{ Contrast } \\
\hline & $\mathrm{CS}$ & EGS & $\mathrm{EGS}+10 \% \mathrm{WB}$ & $\mathrm{EGS}+20 \% \mathrm{WB}$ & & $\mathrm{EGS} \times \mathrm{CS}$ & $\mathrm{EGS}+10 \% \mathrm{WB} \times \mathrm{CS}$ & $\mathrm{EGS}+20 \% \mathrm{WB} \times \mathrm{CS}$ \\
\hline Urination $\left(\mathrm{n} \mathrm{d}^{-1}\right)$ & 13.20 & 11.00 & 9.60 & 9.20 & 30.266 & ns & ns & ns \\
\hline Defecation $\left(\mathrm{n} \mathrm{d}^{-1}\right)$ & 14.40 & 14.00 & 12.00 & 10.10 & 25.465 & ns & ns & ns \\
\hline Water ingestion $\left(\mathrm{n} \mathrm{d}^{-1}\right)$ & 2.50 & 2.40 & 2.70 & 2.30 & 41.948 & ns & ns & ns \\
\hline
\end{tabular}

$\mathrm{CV}$ - coefficient of variation; ns - not significant.

CS - corn silage; EGS - elephant-grass silage without wheat bran; EGS $+10 \% \mathrm{WB}$ - elephant-grass silage $+10 \%$ wheat bran (as is); EGS $+20 \% \mathrm{WB}-$ elephant-grass silage $+20 \%$ wheat bran (as is). 


\section{Conclusions}

Corn silage can be replaced by elephant-grass silage harvested at 50 days of regrowth without influencing performance, behavioral and physiological variables, or production and physicochemical composition of milk from goats. The use elephant-grass silages enriched with $10 \%$ wheat bran can also be a good alternative for producers in that this roughage provides a similar milk yield to lactating goats as compared with corn or elephant-grass silages without any additive.

\section{References}

Alves, A. R.; Medeiros, A. N. and Costa, M. G. 2010. Consumo e digestibilidade aparente de cabras leiteiras utilizando dietas com diferentes fontes de nitrogênio. In: Anais da 47a Reunião Anual da Sociedade Brasileira de Zootecnia. Sociedade Brasileira de Zootecnia, Salvador.

AOAC - Association of Official Analytical Chemists. 1998. Official methods of analysis. 16th ed. AOAC International, Arlington, VA.

Brasil. Ministério da Agricultura e do Abastecimento. Secretaria Nacional de Defesa Agropecuária. 2000. Instrução Normativa $n^{\circ} 37$, de 31 de outubro de 2000. Regulamento técnico de produção, identidade e qualidade do leite de cabra. Diário Oficial da União, Brasília, 8 nov. 2000.

Bolsen, K. K.; Lin, C. and Brent, B. E. 1992. Effect of silage additives on the microbial succession and fermentation process of alfalfa and corn silages. Journal of Dairy Science 75:3066-3083.

Bürger, P. J.; Pereira, J. C.; Queiroz, A. C.; Silva, J. F. C.; Valadares Filho, S. C.; Cecon, P. R. and Casali, A. D. P. 2000. Comportamento ingestivo em bezerros holandeses alimentados com dietas contendo diferentes níveis de concentrado. Revista Brasileira de Zootecnia 29:236-242.

Cândido, M. J. D. 2000. Qualidade e valor nutritivo de silagens de híbridos de sorgo (Sorghum bicolor (L.) Moench) sob doses crescentes de recomendação de adubação. Dissertação (M.Sc.). Universidade Federal de Viçosa, Viçosa, MG.

Casali, A. O. 2006. Procedimentos metodológicos in situ na avaliação dos compostos indigestíveis em alimentos e fezes de bovinos. Dissertação (M.Sc.). Universidade Federal de Viçosa, Viçosa, MG.

Dulphy, J. P.; Remond, B. and Theriez, M. 1980. Ingestive behavior and related activities in ruminants. p.103-122. In: Digestive physiology and metabolism in ruminants. Ruckebush, Y. and Thivend, P., eds. MTP, Lancaster.

Ferreira, J. J. 2001. Características qualitativas e produtivas da planta de milho e sorgo. p.383-404. In: Produção e utilização de silagem de milho e sorgo. Cruz, J. C.; Pereira Filho, I. A.; Rodrigues, J. A. S. and Ferreira, J. J., eds. EMBRAPA, Sete Lagoas.

Hall, M. B.; Hoover, W. H.; Jennings, J. P. and Webster, T. K. M. 1999. A method for partitioning neutral detergent soluble carbohydrates. Journal of the Science of Food Agriculture 79:2079-2086.

Hall, M. B. 2000. Calculation of non-structural carbohydrate content of feeds that contain non-protein nitrogen. Bulletin n. 339. University of Florida, Gainesville.

Harris, P. and James, A. T. 1969. The effect of low temperatures on fatty acid biosynthesis in plants. Biochemical Journal 325-330.

IAL - Instituto Adolfo Lutz. 2005. Normas analíticas do Instituto Adolfo Lutz. Instituto Adolfo Lutz, São Paulo.

Johnson, T. R. and Combs, D. K. 1991. Effects of prepartum diet, inert rumen bulk, and dietary polyethylene glycol on dry matter intake of lactating dairy cows. Journal Dairy Science 74:933-944

Lanes, E. C. M.; Oliveira, J. S.; Lopes, F. C. F. and Villani, E. M. A. 2006. Silagem de milho como alimento para o período da estiagem: como produzir e garantir qualidade. Revista CES 20:97-111.

Martin, P. and Bateson, P. 1986. Measuring behavior and introductory guide. 3th ed. Cambridge University Press, New York.

Menezes, M. P. C.; Ribeiro, M. N.; Costa, R. G. and Medeiros, A. N. 2004. Substituição do milho pela casca de mandioca (Manihot esculenta Crants) em rações completas para caprinos: consumo, digestibilidade de nutrientes e ganho de peso. Revista Brasileira de Zootecnia 33:729-737.

NRC - National Research Council. 2001. Nutrient requirements of dairy cattle. 7th ed. NRC, Washington, DC.

NRC - National Research Council. 2007. Nutrient requirement of small ruminants. 1st ed. NRC, Washington, DC.

Polli, V. A.; Restle, J.; Senna, D. B. and Almeida, S. R. S. 1996. Aspectos relativos à ruminação de bovinos e bubalinos em regime de confinamento. Revista da Sociedade Brasileira de Zootecnia 25:987-993.

Silva, D. J. and Queiroz, A. C. 2002. Análise de alimentos. 3.ed. UFV, Viçosa, MG

Silva, J. F. C. and Leão, M. I. 1979. Fundamentos de nutrição dos ruminantes. Livroceres, Piracicaba.

Sniffen, C. J.; O’Connor, J. D.; Van Soest, P. J.; Fox, D. G. and Russell, J. B. 1992. A net carbohydrate and protein system for evaluating cattle diets: II. Carbohydrate and protein availability. Journal of Animal Science 70:3562-3577.

Van Soest, P. J. 1967. Development of a comprehensive system of feed analysis and its applications to forages. Journal of Animal Science 26:119-128.

Van Soest, P. J. 1994. Nutritional ecology of the ruminant. 2th ed. Cornell University Press, Ithaca, NY.

Tyrrel, H. F. and Reid, J. T. 1965. Prediction of energy value of cow's milk. Journal of Dairy Science 48:1215-1223. 